\title{
Implementasi Kansei Engineering Dalam Perancangan Desain Karakter dengan Prinsip Appeal (Studi Kasus: Karakter dalam Film Battle of Surabaya)
}

\author{
Kansei Engineering Implementation in Designing Character with Appeal \\ Principle (Case Study: Characters in the Film Battle of Surabaya)
}

\author{
Dessy Riana Sari*1, M. Suyantoº ${ }^{2}$, Amir Fatah Sofyan ${ }^{3}$ \\ 1,2,3 Universitas Amikom Yogyakarta \\ E-mail: *1 dessyriana13@students.amikom.ac.id, ${ }^{2}$ yanto@amikom.ac.id, \\ 3amir@amikom.ac.id
}

\begin{abstract}
Abstrak
Dalam penciptaan desain karakter animasi erat kaitanya dengan prinsip Appeal, namun prinsip animasi ini sangat bergantung terhadap penilaian pribadi. Sehingga diperlukan cara yang sistematis untuk memahami penilaian prinsip appeal dalam penciptaan degain karakter animasi. Penelitian ini menggunakan Metode Kansei Engeneering untuk mendapatkan penilaian mengenai prinsip appeal dengan menggunakan studi kasus karakter dari animasi Battle of Surabaya. Metode Kansei Engeneering digunakan berdasarkan perasaan psikologis yang tercermin melalui kata kansei. Analisis yang digunakan dalam penelitian ini menggunakan analisis statistik multivariant. Hasil dari penelitian ini memberikan rekomendasi elemen desain karakter yang dihasilkan dengan prinsip appeal melalui pendekatan Kansei Engenering. Elemen desain pada penelitian ini diperoleh dari studi kasus karakter animasi di film Battle of Surabaya yang berpedoman dengan Kansei Word. Hasil analisis menunjukan bahwa pengaruh appeal pada design karakter dapat dicapai dengan elemen desain seperti Teritary Color, Near Realis, Hooded Eyes, dan Square Face Shape. Penelitian ini diharapkan dapat memberikan kontribusi ilmiah mengenai penciptaan desain karakter yang mengacu pada prinsip appeal.
\end{abstract}

Kata Kunci-Kansei Engeneering, Appeal, Desain Karakter

\begin{abstract}
When created animated character designs closely related to the principle of Appeal, but the principle of animation is very dependent on personal judgment. A systematic way to understand the appraisal principle is required in the creation of animated characters. This research uses Kansei Engeneering Method to get consideration of comparative principles by using case studies of characters from the Battle of Surabaya animation. The Kansei Engeneering method is used based on psychological feelings that are reflected through the word kansei. The analysis in this research uses multivariate statistical analysis. This researchy provides recommendations for the character design elements produced with the principle of appeal through the Kansei Engenering approach. The design elements in this study were obtained from a case study of animated characters in the film Battle of Surabaya, which is guided by Kansei Word. The analysis shows that the effect of appeal on character design can be achieved with design elements such as Teritary Color, Near Realist, Hooded Eyes, and Square Face Shape. This research is expected to make a scientific contribution regarding the creation of character designs that refer to the principle of appeal.
\end{abstract}

Keywords-Kansei Engeneering, Appeal, Character design 


\section{PENDAHULUAN}

Film sebagai karya fiksi memiliki karakter dengan pembagian peran tertentu. Karakter merupakan satu elemen penting yang ada dalam narasi dibuat berdasarkan kualitas mental, emosional, dan social [1]. Karakter juga merupakan salah satu penggerak cerita, bagaimana cerita itu bergulir, arah dan tujuan sampai pada transformasi sebuah tokoh atau karakter. Setiap karakter animasi dikembangkan hingga demikian rupa sehingga memiliki daya Tarik (prinsip animasi appeal) yang unik dan membedakan dengan karakter lainnya berdasarkan peran yang dibawakan [2]. Karakter animasi sangat mempengaruhi pola fikir penonton. Karakter animasi yang menarik dan unik menjadi poin penting untuk menarik perhatian penonton. Selain itu, karakteristik dari karakter animasi yang mencerminkan pola hidup dari suatu budaya menjadi acuan penonton untuk memilih karakter yang disukai [3]. Misalnya karakter jahat digambarkan dengan gigi yang runcing, wajah yang panjang, dan alis yang mengkerut. Suatu contoh Karakter yang ada dalam film animasi berjudul "Finding Nemo" memiliki ciri khas tersendiri yang melekat dalam ingatan penonton. Prinsip animasi appeal juga merupakan prinsip animasi yang mampu membuat design karakter terlihat lebih menonjol [4]. Penonton dengan mudah tertarik atau menyukai terhadap karakter yang di buat dengan mengunakan prinsip appeal.

Saat seorang designer karakter atau animator menciptakan sebuah karakter fiksi, tidak cukup dengan hanya membuat tampilan yang menarik secara visual, namun kemampuan dalam menciptakan sebuah karakter diperlukan kemampuan untuk membangun sebuah karakter yang benar benar meyakinkan seperti bagaimana karakter animasi dapat memberi ilusi mengenai kehidupan, memiliki motivasi, berfikir dan bertindak layaiknya dalam kehidupan sebenarnya [5]. Pemanfaatan multimedia yang memungkinkan pemakai komputer untuk mendapatkan output dalam bentuk yang lebih kaya dari pada konvensional juga berpengaruh [6].

Dalam hal ini faktor psikologis / emosional penonton menjadi parameter dalam perancangan design karakter oleh karena itu Kansei Engineering (KE) dilibatkan sebagai pendekatan analisis dalam penelitian ini.

Kansei Engeneering merupakan metode penelitian dengan aspek emosional dalam perancangan antarmuka sistem informasi berbasis web berdasarkan disiplin ilmu matematika, statistik, psikologi dan teknik informatika yang memungkinkan pengukuran aspek emosional konsumen terhadap suatu produk dan menghubungkan hasil aspek emosional tersebut terhadap elemen perancangan produk [7]. Penelitian ini menjabarkan penerapan prinsip animasi appeal yang digunakan pada design karakter dalam animasi Battle of Surabaya dengan pendekatan Kansei Engeneering. Dan memberikan rekomendasi elemen design karakter yang dihasilkan dengan prinsip appeal melalui pendekatan Kansei Engeneering.

\section{METODE PENELITIAN}

Metode yang digunakan dalam penelitian ini mengacu pada Kansei Engeneering Type I yang menafsirkan sebuah konsep desai menjadi sub konsep dan akan manafsirkan karakteristik fisik dari desain produk [8]. Terdapat sepuluh tahap yang diuraikan pada Gambar 1 berikut. 
Citec Journal, Vol. 7, No. 2, Juli 2020

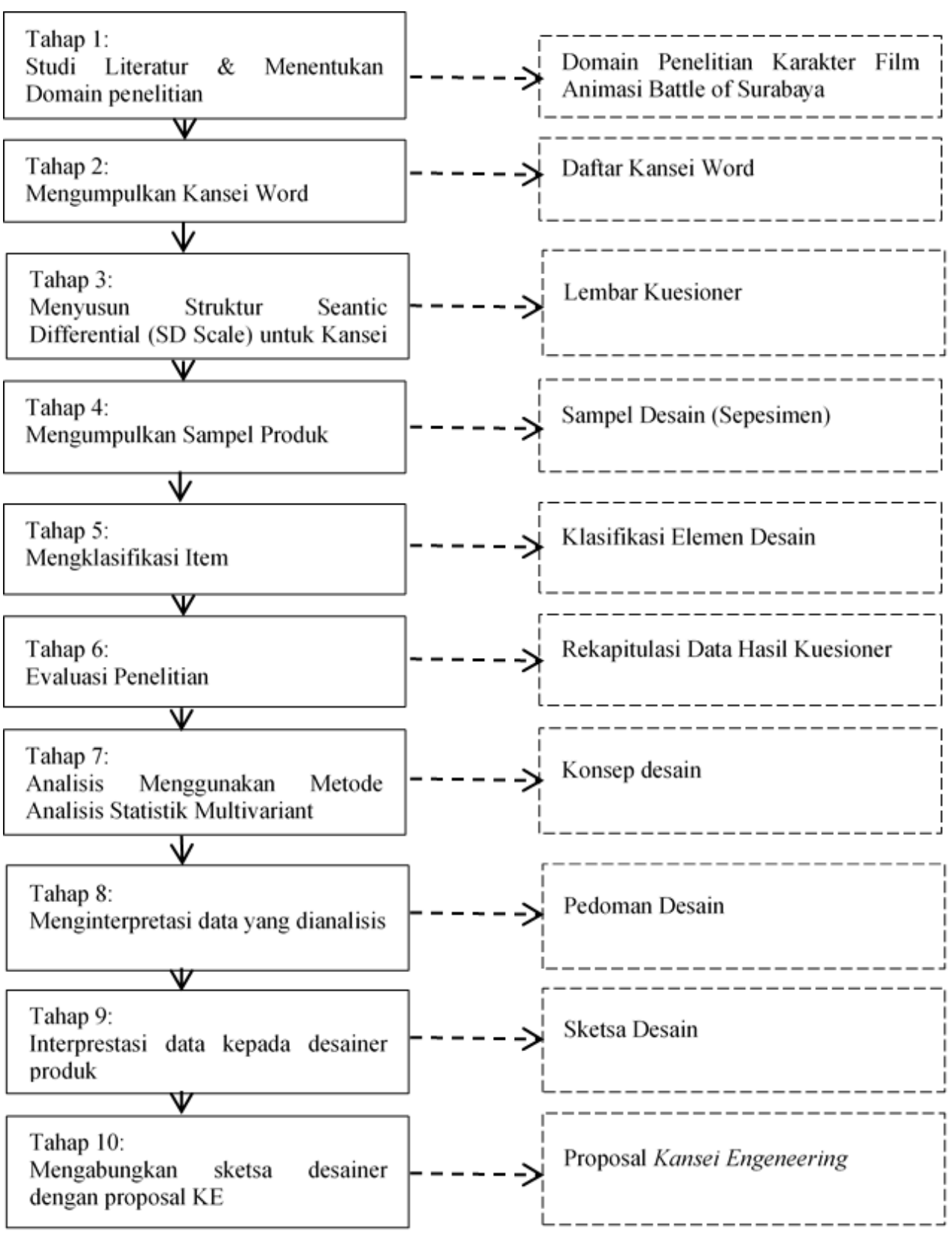

Gambar 1. Tahapan penelitian dalam Kansei Engeneering Type 1

Pengumpulan Kansei Words Pada awal penelitian kata pencarian yang akan diimplementasikan dalam Kansei Word, Kansei Word yang diperoleh dengan cara wawancara dari responden akan diidentifikasi, dimana peneliti akan pengelompokan kata tersebut yang bermakna sama. Selanjutnya kata Kansei Word dieliminasi dengan memilih jumlah kata kansei terbanyak berdasarkan pemilihan responden. Proses pensisian kuesioner tidak dengan cara manual, namun menggunakan form yang dapat diakses masing masing responden menggunakan jaringan internet. Responden pada penelitian ini adalah para design karakter, animator, dan masyarakat umum. Cara yang digunakan untuk pengambilan sample adalah dengan wawancara dan kuesioner. Jumlah sampel yang ditentukan sebanyak 50 responden.

Analisis statistik multivariat digunakan untuk beberapa variabel yang memiliki hubungan antar variabel saling berkorelasi [9]. Terdapat 4 analisis statistik yang digunakan dalam analisis ini yaitu: Cronbach's Alpha, Coefficient Correlation Analysis (CCA), Principal Component Analysis (PCA), dan Factor Analysis (FA) [10]. 


\section{HASIL DAN PEMBAHASAN}

Tahap ini diawali dengan mengumpulkan kata-kata Kansei yang berkaitan dengan elemen desain karakter. Kata-kata Kansei tersebut dihimpun dari sejumlah literatur desain karakter seperti buku referensi, majalah dan wawancara dengan responden dari desain karakter pada film Battle of Surabaya. Kansei Engeneering type 1 digunakan dalam analisis penelitian ini dengan melibatkan 7 spesimen. 20 Kansei Word disusun kedalam skala SD dan melibatkan 50 Partisipan. 20 Kansei Word dapat dilihat pada Tabel 1.

Tabel 1. Kansei Word dalam penelitian

\begin{tabular}{clclclcl}
\hline No & Kansei Word & No & Kansei Word & No & Kansei Word & No & Kansei Word \\
\hline 1 & Keren & 6 & Bibir mungil & 11 & Pipi Chubby & 16 & Badan Pendek \\
\hline 2 & Tomboi & 7 & Mata lebar & 12 & Rambut Rapi & 17 & Bekas Luka \\
\hline 3 & Badan Tegap & 8 & Mata Lancip & 13 & Pemberani & 19 & Badan Ramping \\
\hline 4 & Lugu & 9 & Rambut Panjang & 14 & Wajah Tegas & 18 & Imut \\
\hline 5 & Feminim & 10 & Jenggot/ Kumis & 15 & Postur Tinggi & 20 & Misterius \\
\hline
\end{tabular}

Kansei Word yang sudah diseleksi mempresentasikan karakteristik elemen prinsip appeal, kemudian distrukturkan kedalam skala SD dengan menggunakan 5 Skor penilaian, nilai tertinggi, angka 5 menunjukan sangat setuju dan nilai terendah dangan angka 1 menunjukan sangat tidak setuju. Kuisioner Kansei Word dalam skala SD tersaji dalam tabel 2.

Tabel 2. Kuesioner Kansei Word dalam Skala SD

\begin{tabular}{|c|c|c|c|c|c|c|c|}
\hline \multirow{2}{*}{ No } & \multirow{2}{*}{ Kansei Word } & \multicolumn{5}{|c|}{ Skor Penilaian } & \multirow{2}{*}{ Kansei Word } \\
\hline & & 5 & 4 & 3 & 2 & 1 & \\
\hline 1 & Keren (Tampak gagah dan tangkas) & & & & & & Tidak Keren \\
\hline 2 & $\begin{array}{l}\text { Tomboi (Perempuan dengan sifat kelaki- } \\
\text { lakian) }\end{array}$ & & & & & & Tidak Tomboi \\
\hline 3 & Lugu (bersahaja, apa adanya) & & & & & & Tidak Lugu \\
\hline 4 & Feminim (Menonjolkan sifat kewanitaan) & & & & & & Tidak Feminim \\
\hline
\end{tabular}

\subsection{Spesimen Desain Karakter}

Dari beberapa desain karakter dalam film animasi battle of Surabaya dipilih sebanyak 7 spesimen yang memiliki karakteristik yang berbeda - beda, berdasarkan jenis kelamin, penggambaran usia karakter, dan watak karakter. Tabel 3 adalah paparan data spesimen.

Tabel 3. Data Spesimen

\begin{tabular}{lccccccc}
\hline ID & $\mathbf{1}$ & $\mathbf{2}$ & $\mathbf{3}$ & $\mathbf{4}$ & $\mathbf{5}$ & $\mathbf{6}$ & $\mathbf{7}$ \\
\hline Nama & Musa & Yumna & Danu & Kazuhiro & $\begin{array}{c}\text { John } \\
\text { Wright }\end{array}$ & Yoshimura & Kioko \\
$\begin{array}{l}\text { Tampilan } \\
\text { Visual }\end{array}$ & & & & & & & \\
\end{tabular}


Citec Journal, Vol. 7, No. 2, Juli 2020

ISSN: 2354-5771

Selanjutnya 7 spesimen tersebut yaitu karakter Musa, Yumna, Danu, Kazuhiro, John Wright, Yoshimura, dan Kioko yang didapat dari web MSV Pictures diubah kedalam elemen desain untuk diuraikan, penguraian tersebut dimulai dengan kategori utama yaitu, Shape Theory, Colour Theory, Level of Simplify, Anatomy, Defining a character. Kemudian didapatkan data berikut:

1. Lima kategori elemen desain: Shape Theory, Colour Theory, Level of Simplify, Anatomy, Defining a character.

2. Terdapat 10 sub elemen desain yang merupanak penjabaran dari 5 kategori elemen desain.

3. Terdapat 64 kategori yang merupakan rincian dari 10 sub element desain. Klasifikasi tersebut seperti ditunjukan pada Tabel 4.

Tabel 4. Klasifikasi Elemen Desain

\begin{tabular}{|c|c|c|c|c|c|c|c|}
\hline \multirow[b]{2}{*}{ ID } & \multicolumn{4}{|c|}{ Shape Theory } & \multicolumn{2}{|c|}{ Temperature Colour } & \multirow{2}{*}{$\ldots$} \\
\hline & Square & Triangels & Circles & Combinations & $\begin{array}{l}\text { Warm } \\
\text { Colour }\end{array}$ & $\begin{array}{c}\text { Cool } \\
\text { Colour }\end{array}$ & \\
\hline 1 & & & & $\checkmark$ & & $\checkmark$ & $\ldots$ \\
\hline 2 & & & & $\checkmark$ & $\checkmark$ & & $\ldots$ \\
\hline 3 & & & & $\checkmark$ & & $\checkmark$ & ... \\
\hline 4 & & & & $\checkmark$ & & $\checkmark$ & $\ldots$ \\
\hline 5 & & & & $\checkmark$ & & $\checkmark$ & $\ldots$ \\
\hline
\end{tabular}

\subsection{Pengambilan Data Kuesioner}

Pada skala SD yang telah didapat, kemudian didistribusikan kepada 50 partisipan. Hasil rekapitulasi kuesioner terdapat pada Tabel 5 . Nilai dari rata rata hasil rekapitulasi tersebut kemudian digunakan untuk analisis statistik multivariant.

Tabel 5. Rata Rata hasil Rekapitulasi Responden

\begin{tabular}{clccccccc}
\hline \multirow{2}{*}{ No } & \multirow{2}{*}{ Kansei Word } & \multicolumn{7}{c}{ ID Karakter } \\
\cline { 3 - 8 } & & $\mathbf{1}$ & $\mathbf{2}$ & $\mathbf{3}$ & $\mathbf{4}$ & $\mathbf{5}$ & $\mathbf{6}$ & $\mathbf{7}$ \\
\hline 1 & Keren & 4.49 & 4.28 & 5.00 & 4.95 & 4.25 & 3.62 & 3.89 \\
\hline 2 & Misterius & 3.42 & 2.01 & 4.29 & 4.99 & 4.62 & 4.96 & 3.84 \\
\hline 3 & Badan Tegap & 4.21 & 3.01 & 4.78 & 4.26 & 3.29 & 3.27 & 3.13 \\
\hline 4 & Lugu & 4.00 & 3.27 & 3.01 & 2.01 & 2.64 & 3.14 & 3.84 \\
\hline 5 & Feminim & 3.04 & 4.99 & 2.08 & 2.05 & 2.04 & 2.04 & 4.78 \\
\hline 6 & Pemberani & 4.92 & 4.98 & 4.97 & 4.75 & 3.98 & 4.03 & 3.02 \\
\hline 7 & Mata lebar & 3.86 & 3.72 & 3.09 & 3.29 & 3.42 & 2.04 & 4.02 \\
\hline 8 & Mata Lancip & 2.93 & 3.17 & 3.20 & 3.98 & 3.57 & 3.56 & 4.28 \\
\hline 9 & Rambut Panjang & 2.94 & 4.94 & 3.74 & 3.02 & 1.03 & 2.94 & 4.28 \\
\hline 10 & Jenggot/ Kumis & 1.40 & 2.03 & 3.74 & 2.48 & 3.84 & 4.08 & 2.04 \\
\hline 11 & Pipi Chubby & 2.09 & 3.95 & 2.09 & 2.08 & 2.74 & 2.30 & 4.28 \\
\hline 12 & Rambut Rapi & 3.94 & 4.20 & 3.45 & 3.75 & 2.04 & 3.04 & 3.99 \\
\hline 13 & Bibir Mungil & 3.08 & 2.90 & 3.08 & 2.08 & 2.40 & 2.04 & 3.45 \\
\hline 14 & Wajah Tegas & 4.98 & 3.95 & 3.08 & 4.97 & 4.68 & 3.74 & 3.04 \\
\hline 15 & Postur Tinggi & 3.07 & 3.09 & 4.27 & 4.75 & 4.97 & 3.59 & 2.04 \\
\hline 16 & Badan Pendek & 3.09 & 3.20 & 2.03 & 2.04 & 2.04 & 2.03 & 3.05 \\
\hline 17 & Bekas Luka & 2.71 & 2.45 & 2.05 & 4.02 & 3.85 & 2.58 & 2.00 \\
\hline 18 & Badan Ramping & 3.60 & 4.29 & 3.59 & 3.05 & 3.05 & 3.02 & 3.20 \\
\hline 19 & Imut & 4.01 & 4.34 & 2.49 & 2.04 & 2.40 & 2.04 & 4.40 \\
\hline 20 & Tomboi & 3.01 & 4.98 & 4.32 & 2.42 & 3.23 & 2.40 & 3.02 \\
\hline
\end{tabular}




\subsection{Hasil Analisis Multivariant}

Terdapat beberapa relasi antar variabel karenanya digunakan analisis multivariant dengan melibatkan Coefficient Correlation Analysis (CCA), Principal Component Analysis (PCA) dan Factor Analysis (FA). Berikut ini hasil dari ketiga analisis tersebut.

\subsubsection{Coefficient Correlation Analysis (CCA)}

Untuk mengetahui korelasi antar Kansei Word perlu dilakukan CCA dengan metode korelasi Pearson, hasil dari analisis tersebut ditunjukan pada tabel 6.

Tabel 6. Hasil Anialisa CCA

\begin{tabular}{lrrrrrrr}
\hline \multicolumn{1}{c}{ Variables } & Keren & Misterius & $\begin{array}{r}\text { Badan } \\
\text { Tegap }\end{array}$ & Lugu & Feminim & Pemberani & $\ldots$ \\
\hline Keren & $\mathbf{1}$ & 0.047 & $\mathbf{0 . 8 3 5}$ & -0.442 & -0.324 & 0.691 & $\ldots$ \\
\hline Misterius & 0.047 & $\mathbf{1}$ & 0.311 & -0.540 & $\mathbf{- 0 . 8 2 6}$ & -0.286 & $\ldots$ \\
\hline Badan Tegap & $\mathbf{0 . 8 3 5}$ & 0.311 & $\mathbf{1}$ & -0.217 & -0.554 & 0.584 & $\ldots$ \\
\hline Lugu & -0.442 & -0.540 & -0.217 & $\mathbf{1}$ & 0.587 & -0.233 & $\ldots$ \\
\hline Feminim & -0.324 & $\mathbf{- 0 . 8 2 6}$ & -0.554 & 0.587 & $\mathbf{1}$ & -0.233 & $\ldots$ \\
\hline Pemberani & 0.691 & -0.286 & 0.584 & -0.233 & -0.233 & $\mathbf{1}$ & $\ldots$ \\
\hline Mata lebar & 0.237 & -0.592 & -0.057 & 0.377 & 0.646 & -0.054 & $\ldots$ \\
\hline Mata Lancip & -0.256 & 0.446 & -0.311 & -0.268 & 0.105 & $\mathbf{- 0 . 7 6 4}$ & $\ldots$ \\
\hline Rambut Panjang & -0.002 & -0.647 & -0.090 & 0.388 & 0.738 & 0.117 & $\ldots$ \\
\hline Jenggot/ Kumis & -0.126 & 0.635 & 0.025 & -0.485 & -0.669 & -0.130 & $\ldots$ \\
\hline Pipi Chubby & -0.481 & -0.596 & -0.748 & 0.393 & $\mathbf{0 . 8 9 9}$ & -0.527 & $\ldots$ \\
\hline Rambut Rapi & 0.170 & -0.601 & 0.111 & 0.415 & 0.658 & 0.242 & $\ldots$ \\
\hline Bibir Mungil & 0.048 & -0.595 & 0.043 & 0.750 & 0.662 & -0.144 & $\ldots$ \\
\hline Wajah Tegas & 0.269 & 0.103 & 0.133 & -0.336 & -0.336 & 0.390 & $\ldots$ \\
\hline Postur Tinggi & 0.522 & 0.563 & 0.407 & $\mathbf{- 0 . 8 5 9}$ & $\mathbf{- 0 . 8 1 3}$ & 0.390 & $\ldots$ \\
\hline Badan Pendek & -0.233 & $\mathbf{- 0 . 8 6 0}$ & -0.361 & $\mathbf{0 . 7 5 9}$ & $\mathbf{0 . 8 9 7}$ & -0.042 & $\ldots$ \\
\hline Bekas Luka & 0.273 & 0.447 & 0.056 & -0.748 & -0.519 & 0.137 & $\ldots$ \\
\hline Badan Ramping & 0.199 & $\mathbf{- 0 . 9 2 6}$ & -0.042 & 0.365 & 0.612 & 0.568 & $\ldots$ \\
\hline Imut & -0.223 & $\mathbf{- 0 . 8 5 0}$ & -0.361 & $\mathbf{0 . 7 7 9}$ & $\mathbf{0 . 9 2 1}$ & -0.131 & $\ldots$ \\
\hline Tomboi & 0.260 & -0.754 & -0.031 & 0.170 & 0.472 & 0.433 & $\ldots$ \\
\hline
\end{tabular}

Beberapa appeal menunjukan nilai tingkatan keberpengaruhan, seperti "Badan Tegap dengan Keren” yang memiliki kolerasi yang sangat kuat sebesar 0.835 atau memiliki pengaruh kuat sama halnya antara 'Imut' dengan 'Feminim' yang memiliki pengaruh sebesar 0.921. Namun beberapa appeal menunjukkan tidak adanya keberpengaruhan seperti antara "Lugu" dengan "Keren". Dari analisis CCA dapat diketahui appeal manakah yang tidak memiliki pengaruh untuk direduksi, namun dalam penelitian ini, mengacu pada seluruh appeal digunakan dalam analisis berikutnya untuk mengeksplorasi subjektifitas penilaian elemen desain terhadap appeal.

\subsubsection{Principal Component Analysis (PCA)}

PCA dilakukan untuk mengetahui hubungan antara spesimen dan appeal dengan mereduksi faktor-faktor appeal yang tidak terlalu signifikan. Analisis PCA menggunakan software XLStat 2010 dengan melibatkan data rekapitulasi rata-rata partisipan sebagai bahan analisis data. Berdasarkan perhitungan analisis PCA dihasilkan beberapa faktor atau disebut dengan Principal Component (PC) seperti ditunjukkan oleh Tabel 7. 
Citec Journal, Vol. 7, No. 2, Juli 2020

Tabel 7. Nilai PCA

\begin{tabular}{lrrrrrr}
\hline & F1 & \multicolumn{1}{c}{ F2 } & F3 & \multicolumn{1}{c}{ F4 } & \multicolumn{1}{c}{ F5 } & \multicolumn{1}{c}{ F6 } \\
\hline Eigenvalue & 9.677 & 3.992 & 2.258 & 1.657 & 1.359 & 1.057 \\
\hline Variability (\%) & 48.386 & 19.958 & 11.289 & 8.287 & 6.794 & 5.286 \\
\hline Cumulative \% & 48.386 & 68.344 & 79.633 & 87.920 & 94.714 & 100.000 \\
\hline
\end{tabular}

Eigenvalue digunakan untuk menganalisa layak atau tidaknya suatu faktor baru. Syarat layak menjadi suatu factor baru adalah eigenvalue lebih besar atau sama dengan 1, apabila terdapat factor yang memiliki eigenvalue kurang dari 1 maka faktor tersebut akan dikeluarkan atau tidak digunakan. Terdapat nilai eigenvalue (varians) dan variability yang ditunjukkan pada tabel 7, dengan Eigenvalue F1 dan F2 memiliki nilai sebesar 9,677 dan 3.992 dengan tingkat variability pada F1 sebesar $48.386 \%$ dan F2 sebesar 19.958\%. Pada baris cumulative menunjukan akumulasi F2 sebesar 68.344\% yang artinya nilai F1 dan F2 berpengaruh terhadap prinsip appeal.

Untuk memberikan gambaran dengan prinsip appeal, kemudian dilakukan tiga tahap analisis PCA dengan melakukan kalkulasi untuk menganalisis nilai dari F1 dan F2. Tiga tahapan yang digunakan yaitu:

a. PC Loading, pada tahapan ini dilakukan untuk mengetahui sebaran appeal sehingga dapat ditarik kesimpulan terhadap konsep appeal yang berpengaruh dalam specimen

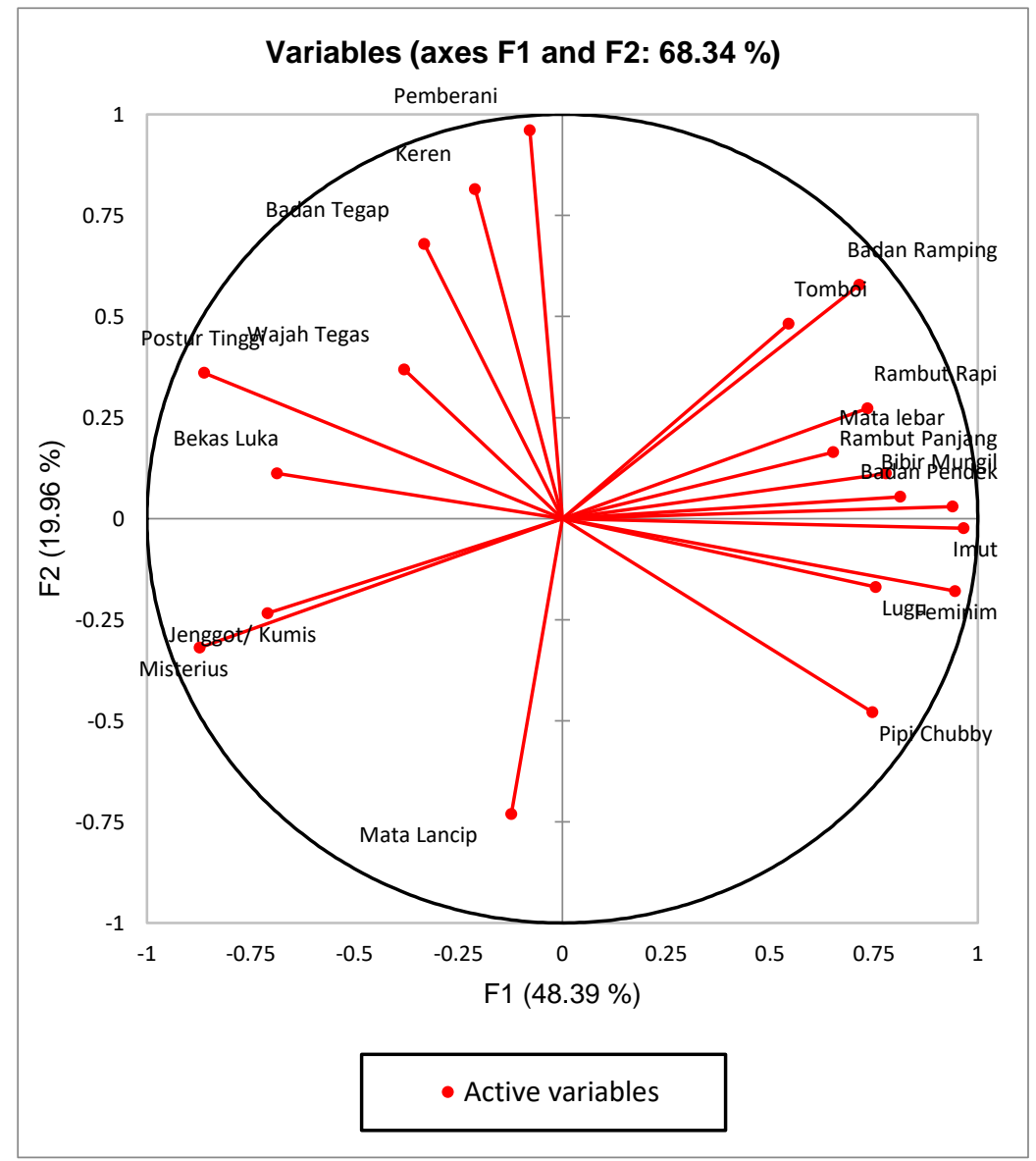

Gambar 2. Hasil PC Loading F1 dan F2

Dari hasil PC Loading pada gambar 1 dapat disimpulkan terdapat dua axis yaitu axis $\mathrm{x}$ dan axis y. Nampak pada axis x terdapat dua appeal yang berlawanan. Bila disimpulkan pada sisi kiri menunjukan hal yang "atraktif” sedangkan sisi kanan menunjukan sebaliknya yaitu "tidak atraktif”. 
b. PC Score, pada tahap ini digunakan untuk mengetahui hubungan antara appeal dan specimen desain karakter. Hasil PC Score dapat dilihat pada Gambar 3.

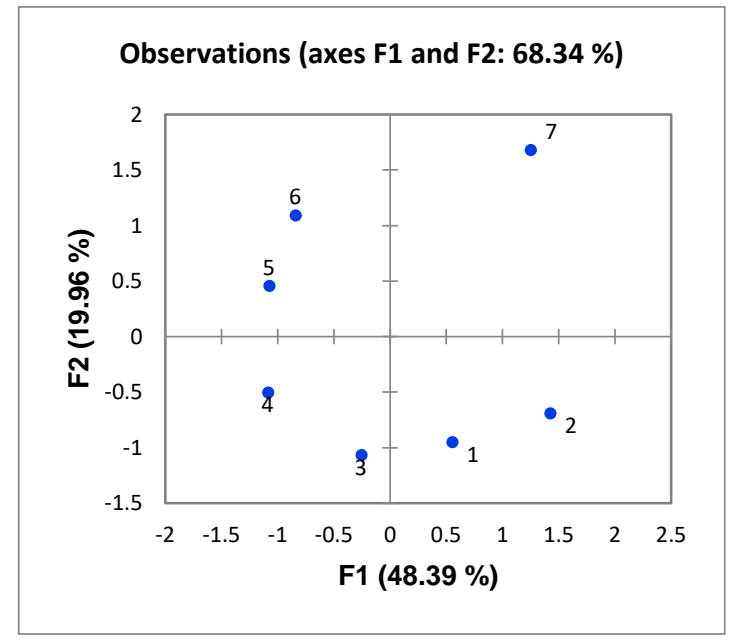

Gambar 3. Hasil PC Score F1 dan F2

Pada Tabel 2 spesimen dengan ID 6, 5, 4, dan 3, pada sisi kiri berada pada sisi atraktif, dan sebaliknya pada axis tidak atraktif dengan specimen ID 7, 2, dan 1.

c. PC Vector adalah tahapan untuk mengetahui seberapa besar pengaruh prinsip appeal dengan spesimen serta menentukan area Kansei dalam perancangan desain karakter. Pada gambar 5 menunjukan dimana posisi area kansei mengacu pada sebaran positif desain karakter dan appeal.

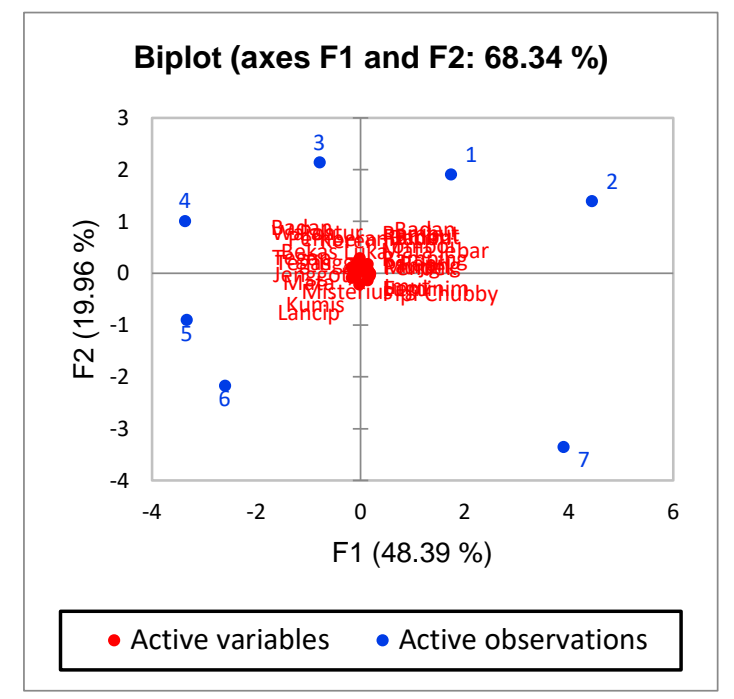

Gambar 4. Area Kansei

PC Vector pada gambar 3 menunjukan nilai dari spesimen, dapat dilihat pada spesimen "3" dan "4" dimana appeal yang mendekati adalah "Pemberani”, "Keren”, dan "Postur Tegap". Sedangkan spesimen "2" dan "7" menunjukan appeal "Imut", "Lugu" dan "Feminim". Kemudian dapat disimpulkan bahwa analisis PCA terhadap F1 dan F2 menghasilkan dua konsep axis X dan Y, yang kemudian dinamakan “Atraktif” dan “Tidak Atraktif”. 
Citec Journal, Vol. 7, No. 2, Juli 2020

\subsubsection{Factor Analysis (FA)}

Setelah mendapatkan hasil dari PCA, Diperlukan analisis lanjutan untuk memperkuat hasil analisis sebelumnya. Factor Analysis digunakan dengan menggunakan varimax rotation untuk memperoleh nilai yang lebih akurat.

Tabel 8. Hasil Analisis Faktor dengan Varimax Rotation

\begin{tabular}{llc}
\hline & D1 & D2 \\
\hline Variability (\%) & 47.009 & 21.334 \\
\hline Cumulative \% & 47.009 & 68.344 \\
\hline
\end{tabular}

Terdapat dua faktor dengan D1 tingkat Variability sebesar 47.009\%, dan D2 sebesar 21.334\%. Hal ini berarti besaran D1 memiliki tingkat keberpengaruhan yang tinggi yakni 47.009\% dan D2 dengan tingkat keberpengaruhan dibawah D1. Pada presentase tersebut D2 dapat dikatakan sudah representative. Bila hasil tersebut dianalisis untuk menentukan nilai appeal, maka terdapat variasi nilai yang berbeda pada setiap appeal.

Tabel 9. Konsep Appeal

\begin{tabular}{lcc}
\hline & D1 & D2 \\
\hline Keren & -0.026 & $\mathbf{0 . 8 4 2}$ \\
\hline Misterius & $\mathbf{- 0 . 9 2 2}$ & -0.119 \\
\hline Badan Tegap & -0.175 & $\mathbf{0 . 7 3 6}$ \\
\hline Lugu & $\mathbf{0 . 6 9 9}$ & -0.331 \\
\hline Feminim & $\mathbf{0 . 8 8 2}$ & -0.382 \\
\hline Pemberani & 0.135 & $\mathbf{0 . 9 5 4}$ \\
\hline Mata lebar & $\mathbf{0 . 6 7 2}$ & 0.017 \\
\hline Mata Lancip & -0.281 & $\mathbf{- 0 . 6 8 5}$ \\
\hline Rambut Panjang & $\mathbf{0 . 7 8 4}$ & -0.063 \\
\hline Jenggot/ Kumis & $\mathbf{- 0 . 7 4 3}$ & -0.072 \\
\hline Pipi Chubby & 0.623 & $\mathbf{- 0 . 6 3 1}$ \\
\hline Rambut Rapi & $\mathbf{0 . 7 7 7}$ & 0.105 \\
\hline Bibir Mungil & $\mathbf{0 . 8 0 5}$ & -0.126 \\
\hline Wajah Tegas & -0.290 & $\mathbf{0 . 4 4 3}$ \\
\hline Postur Tinggi & $\mathbf{0 . 7 6 2}$ & 0.541 \\
\hline Badan Pendek & $\mathbf{0 . 9 2 3}$ & -0.178 \\
\hline Bekas Luka & $\mathbf{- 0 . 6 4 6}$ & 0.261 \\
\hline Badan Ramping & $\mathbf{0 . 8 2 5}$ & 0.407 \\
\hline Imut & $\mathbf{0 . 9 3 7}$ & -0.236 \\
\hline Tomboi & $\mathbf{0 . 6 3 7}$ & 0.350 \\
\hline & &
\end{tabular}

Korelasi pada Tabel 9 disusun berurutan dengan nilai terkecil hingga terbesar untuk mengetahui appeal yang memiliki nilai terbesar. Tabel juga tersebut menunjukan besaran korelasi antara faktor dengan appeal.

Dalam analisis PLS, data statistik diterjemahkan menjadi elemen desain berdasarkan appeal. Hasil dari analisis PLS menghasilkan rekomendasi elemen desain sesuai dengan appeal yang terdapat dalam konsep "atraktif”.

Kategori elemen desain diterjemahkan ke dalam dummy variable dengan mengubah tanda ceklis diberi nilai 1 dan kolom kosong diberi nilai 0 . 
Tabel 10. Dummy Variable

\begin{tabular}{|c|c|c|c|c|c|c|c|c|c|c|c|c|c|c|c|c|c|}
\hline \multirow{3}{*}{ 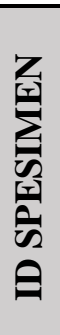 } & \multirow{2}{*}{\multicolumn{4}{|c|}{ Shape Theory }} & \multicolumn{12}{|c|}{ Colour } & \multirow{3}{*}{\begin{tabular}{|c}
$\ldots$ \\
$\ldots$ \\
\\
$\ldots$ \\
\end{tabular}} \\
\hline & & & & & \multicolumn{3}{|c|}{ Basic Colour } & \multicolumn{2}{|c|}{ Temperature } & \multicolumn{7}{|c|}{ Colour Harmony } & \\
\hline & $\begin{array}{l}\tilde{\tilde{n}} \\
\overline{\tilde{n}}\end{array}$ & 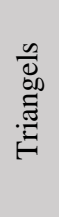 & 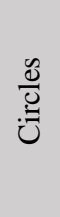 & 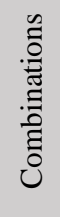 & 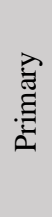 & 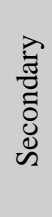 & 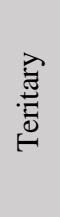 & $\frac{1}{3}$ & $\overline{8}$ & 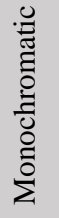 & 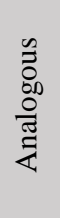 & 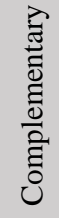 & 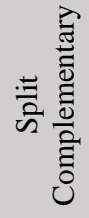 & $\begin{array}{l}\mathscr{\Xi} \\
. \bar{\Xi} \\
.\end{array}$ & & 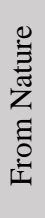 & \\
\hline 1 & 0 & 0 & 0 & 1 & 0 & 0 & 1 & 0 & 1 & 0 & 0 & 0 & 0 & 0 & 0 & 1 & \\
\hline 2 & 0 & 0 & 0 & 1 & 0 & 0 & 1 & 1 & 0 & 0 & 0 & 1 & 0 & 0 & 0 & 0 & $\cdots$ \\
\hline 3 & 0 & 0 & 0 & 1 & 0 & 0 & 1 & 0 & 1 & 0 & 0 & 0 & 1 & 0 & 0 & 0 & \\
\hline 4 & 0 & 0 & 0 & 1 & 0 & 0 & 1 & 0 & 1 & 1 & 0 & 0 & 0 & 0 & 0 & 0 & \\
\hline 5 & 0 & 0 & 0 & 1 & 0 & 0 & 1 & 0 & 1 & 0 & 1 & 0 & 0 & 0 & 0 & 0 & \\
\hline 6 & 0 & 0 & 0 & 1 & 0 & 0 & 1 & 0 & 1 & 0 & 0 & 0 & 1 & 0 & 0 & 0 & \\
\hline 7 & 0 & 0 & 0 & 1 & 0 & 0 & 0 & 0 & 1 & 0 & 1 & 0 & 0 & 0 & 0 & 0 & \\
\hline
\end{tabular}

Data yang dilibatkan dalam analisis PLS adalah Variabel y yang berupa hasil rekapitulasi appeal dari partisipan. Variabel $\mathrm{x}$ yang berupa elemen desain yang diterjemahkan ke dalam dummy variable, dan 7 spesimen desain karakter. Selanjutnya data dummy variable tersebut disebut dengan variabel $\mathrm{x}$ dan variabel $\mathrm{y}$.

Tabel 11. Range Kategori dariHasil Analisis PLS

\begin{tabular}{lr}
\hline \multicolumn{1}{c}{ Kategori } & Range \\
\hline Warm Colour & 0.143 \\
\hline Cool Colour & 0.857 \\
\hline Monochromatic & 0.143 \\
\hline Analogous & 0.286 \\
\hline Complementary & 0.143 \\
\hline Split Complementary & 0.286 \\
\hline Triadic & 0.000 \\
\hline Tetradic & 0.000 \\
\hline From Nature & 0.143 \\
\hline Near Realis & 1.000 \\
\hline Almond Eyes & 0.143 \\
\hline Round Eyes & 0.429 \\
\hline Hooded Eyes & 0.286 \\
\hline Down-turned Eyes & 0.143 \\
\hline$\ldots$ & $\ldots$ \\
\hline
\end{tabular}

Pada tabel 11 nilai range adalah kategori yang memiliki pengaruh terhadap elemen desain. Pada baris "Near Realis" dengan nilai tertinggi sebesar 1.00, berarti kategori tersebut memiliki pengaruh kuat terhadap elemen desain appeal. Sedangkan "Triadic" dan "Tetradic" memiliki nilai range yang lebih rendah ini berarti kategori tersebut tidak memiliki pengaruh terhadap elemen desain appeal.

Pada tabel 12 menunjukan data yang diinterpretasikan pada setiap kategori elemen karakter menggunakan rekomendasi yang ada untuk menciptakan desain karakter dengan prinsip appeal. 
Citec Journal, Vol. 7, No. 2, Juli 2020

Tabel 12. Matriks Rekomendasi Elemen Desain Karakter dengan prinsip Appeal

\begin{tabular}{ll}
\hline & Appeal \\
\hline Elemen Karakter & Rekomendasi \\
\hline Eyes Sape & Hooded \\
\hline Face Shape & Square \\
\hline Nose Shape & Straight \\
\hline Ear Shape & Round \\
\hline Lips Shape & Thin \\
\hline Basic Color & Teritary \\
\hline Temperature Color & Cool \\
\hline Colour Harmony & Analogus \\
\hline Lefel Of Simplify & Near Realis \\
\hline
\end{tabular}

\section{KESIMPULAN}

Perancangan desain karakter dengan prinsip appeal dilakukan dengan pendekatan Kansei Engeneering menghasilkan rekomendasi elemen desain serta melibatkan faktor psikologis. Penerapan Kansei Engineering dengan analisis statistik multivariat yang dilakukan dalam penelitian ini dapat menerjemahkan konsep emosi dan menghasilkan elemen desain berdasarkan appeal, sehingga penelitian ini menghasilkan:

1. Konsep appeal yaitu atraktif yang terdiri dari elemen appeal "Teritary Color”, "Near Realis”, "Hooded Eyes", dan "Square Face Shape"

2. Rekomendasi elemen desain berdasarkan prinsip appeal berupa Matrik (tabel 12).

\section{SARAN}

Saran yang dapat diajukan untuk kesempurnaan penelitian ini, yaitu Perlu melibatkan partisipan yang memiliki pengetahuan mendalam mengenai desain karakter dalam penerapan Kansei Engeneering.

\section{DAFTAR PUSTAKA}

[1] Prakoso, G., 2010, Pengetahuan Dasar Film Animasi, FFTV IKJ Press \& Yayasan Seni Visual Indonesia, Jakarta.

[2] Purnama, W., Andreas, W., 2013, Animasi 2D, Kementrian Pendidikan \& Kebudayaan, Malang

[3] Hayati, R. S., Suyanto, M., \& Sukoco., 2016, Analisis Perbandingan Karakter Doraemon dan Karakter Spongebob Dengan Metode Orson Scott Card, Jurnal Eksplora Informatika, No 1, Vol 6.

[4] Santoso, B. G., 2013, Nganimasi Bersama Mas Be, Elex Media Komputindo, Jakarta

[5] Hooks, E., 2011, Acting for Animators, Routledge, Milton Park - Abingdon

[6] Hidayat, T., 2014, Rancang Bangun Media Interaktif Untuk Kerajinan Tangan Tradisional, Creative Information Technology Journal, No. 3, Vol. 1 
[7] Carreiraa, R., Patrício, L., Jorgea, R. N., Mageeb, C. L., 2013, Development of an extended Kansei Engineering method to incorporate experience requirements in product-service system design, Journal of Engineering Design, No. 10, Vol. 23, Hal. 738-764

[8] Nagamachi, M., Lokman, A. M., 2011, Innovations of Kansei Engineering, CRC Press, Florida

[9] Gudono, 2011, Analisis data Multivariat, BPEE Penerbit, Yogyakarta

[10] Santoso, S., 2015, Statistik Multivariat, Elex Media Komputindo, Jakarta. 